\title{
Geographical starting points the analysis of current rural problems in Montenegro: A case study of the rural settlement of Gnjili Potok
}

\author{
Goran Rajović $^{1, *}$, Jelisavka Bulatović ${ }^{2, * *}$ \\ ${ }^{1}$ Street Vojvode Stepe 252, Belgrade, Serbia \\ Phone: 0038161/ 19-24-850 \\ ${ }^{2}$ Department of Technology and Management, College of Textile Design, \\ Street Starine Novaka 24, Belgrade, Serbia \\ Phone: 003861/ 3082651 \\ *,*E-mail address: dkgoran.rajovic@gmail.com, jelisavka.bulatovic@gmail.com
}

\begin{abstract}
The paper examines a number of socio-economic and geographical factors of rural settlement Gnjili Potok. Isolated traffic and geographical position adversely affects the economic and social development of the settlement. Natural characteristics of the area indicate that the rural economy of the village is not in compliance with all the existing natural conditions. Incompatibility between the existing natural conditions and contemporary rural economy is determined by the overall socioeconomic development factors. The percentage reduction in population in the settlement period 1948 to 2009 , amounted to $-75.1 \%$. The main characteristic of the modern development of the settlement provide processes of industrialization and urbanization. Age groups, due to migration and the reduction of fertility change and take on unfavorable characteristics, reduces the proportion of younger and older increases the proportion of the population. In both cases, the disturbed age structure has a reverse effect on the movement of the population (the size of reproductive contingent), but also to all other structures of the population (the size of contingent employment, population, compulsory school contingent, contingent dependent population ratio). The paper, in the end, given the potential and limitations of socio-economic development of the settlement as well as the survey results, and the analysis focuses on whether the respondents and their perceptions of the quality of living conditions in the village.
\end{abstract}

Keywords: Rural settlement Gnjili Potok; geographical location; natural characteristics; social factors; economic factors; survey

\section{INTRODUCTION}

Rural settlement Gnjili Potok affected by deep and contradictory processes, on the one hand, occurs spontaneously urbanization and industrialization of agriculture, and on the other, and on the other, social and economic ruin, and an immense fortune, not only historically valuable way of life.

Gnjili Potok "on are threshold of the twenty-first century, lost his job and biologically the most vital part of the population. In a rural village are sharpening elderly households, over 
time less and less able to sustain agricultural production and valued. Many branches of production and production areas are neglected, and the forest, bushes and weeds, a spontaneous basis, they start again" [1]. In the following statistical census (2021), it could be expected, and on the basis of population and the number of households, fighting rural village, and its biological reduction to a minimum. However, given the fact that the Gnjili Potok not noticed more and more important misappropriation of property ownership (land), however, could be expected restoration (rehabilitation) and the population of the village on a new economic basis, and especially tourism.

Beginning in the seventies was a watershed moment. That in this period start with preserving village, road construction infrastructure, small business development, today Gnjili Potok would not confirm the model chosen as representative (typical), since in all categories of the dominant figures as the widespread occurrence and trends in the rural areas of Montenegro, and we think that we treat underdeveloped. The purpose of this study was to determine to what extent, analyzed and displayed differentiated processes of social and economic development in the rural settlement Gnjili Potok, a factor of disturbance for its social and economic development. From natural conditions shows that economic development does not comply with all the existing natural conditions.

Responsible role in developing the concept of rural development, which will be based on the natural and socio-economic potential of the settlement, to be sure that there are geographical science, especially social and economic geography, that its holistic approach to consolidate research efforts and results of other scientific disciplines.

\section{RELATED WORK}

Although social research needs of rural areas in Montenegro undeniable, in this regard we are able to meet their own current and other needs. In this respect, far behind are European and even neighboring countries. Thus affirm clearly formulated position Jaćimović [2]"and that this follows because today more popular studies of large areas where they cannot even see the problems of the small spatial units - rural villages. Problems (demographic, social and economic) have in each of our countryside and some are so transformed under the influence of urbanization and land reclamation, they gradually lost its former agricultural function. These problems may stem from the general social attitude towards agriculture and its present state, with a lot of trouble and uncertainty, and hence, I guess, and sometimes disparaging attitude toward some of the work only once, rural settlement "?!

As for the lack of literature, as well as the fact that, prior to seventeen years, there was not a comprehensive text, which is treated from the standpoint of any scientific discipline, Gnjili Potok. There are, in fact, only a few important scientific papers in which only mentioned in passing, Gnjili Potok. In this regard, let us mention: Vešović [3], Lutovac [4], Dašić [5]. It was not until 1995, that the 1999 appeared first monographic Rajović [6] and Rajović [7]. The above mentioned issues provide historical - sociological view Gnjilog Potoka and make a modest contribution to the understanding of these issues, so we are as such used in our study. Surveys of rural settlement Gnjili Potok, continue the authors of this text: Rajović [8], Rajović [9], Rajović and Rajović [11], Rajović and Bulatović [12].

Hopefully, that will start researching rural settlement in Montenegro, replace the current lack of geographical studies and emphasize the importance of a geographical perspective in the study of rural village. In this situation, it seems that every research study in the field of rural 
settlements, welcome, therefore, we believe that, in this context, and this modest contribution, can be useful.

\section{RESEARCH METHODOLOGY}

Objective of this study it was possible to realize the combined use of different research methods. The core of the methodological procedure used in this paper makes geographic (spatial) method. Permeated through the entire text of the method and integrity, thanks to which we are able to recognize, define and assess potential natural and socio-economic development of the settlement limits. For data collection pertaining to the analysis of the perception of the quality of living conditions in the village, used a survey research which was conducted in July 2010 and August 2011, a sample of 69 respondent's village.

The scientific explanation of terms, by two methods: analytic and synthetic. Analytical methods were considered certain economic and geographic dimensions of the case studies. Since work has essentially synthetic character, used the results published in the international literature. Among them this time emphasize this: Glendinning, Nuttall, Hendry, Kloep, Wood [13], Corbett [14], Heley and Jones [15], Joshi and Gebremedhin [16].

\section{RESULTS AND DISCUSSION}

\section{1. Geography position}

Rural settlement Gnjili Potok is located in the southeastern part of Andrijevica. The north and northwest sides limited to Bulcem $(1632 \mathrm{~m})$ and saddle Trešnjevik $(1573 \mathrm{~m})$, the north-eastern side Javorovim Brdom $(1685 \mathrm{~m})$ and Lisom $(1978 \mathrm{~m})$, to the east side Pelinovicom $(1642 \mathrm{~m})$, on the southeast side pasture Đekić to Vučjeg Kamena (1100 m), from the south hamlet Miravčine, on the southwest side hamlet Čuka and Stojanovim Lazom.

Gnjili Potok occupies a total area of $8.83 \mathrm{~km}^{2}$ covering an area of $8,83 \mathrm{~km}^{2}$. It is surrounded by two rural settlements: Bare Kraljske and Kralje. Gnjili Potok away from of 8 $\mathrm{km}$ Andrijevica, Mateševa $15 \mathrm{~km}$, Berana $23 \mathrm{~km}$ and Kolašina $28 \mathrm{~km}$. To rural settlement Gnjili Potok is coming from two directions. Most often it comes from the Andrijevice, through rural villages Kralje or from the direction of Kolašina (roads prime importance), through rural villages Bare Kraljske. Until the rural settlement Gnjili Potok is also possible to reach vehicular traffic from rural settlement of the Vranještica, through Bačkog Brda and Lisa, that is, from bare foothills of Komova, through Štavne.

Both roads are joined at the saddle Trešnjevik. Transport and communications of settlement roads increased from the hamlet Čuka, through the Lomova to the foot Trešnjevik, as the road from the hamlet Miravčine. However, all of these roads are of poor quality (macadam) and seasonal character, mostly impassable in winter.

That traffic isolation and distance of major commercial centers, was held on the negative socio-economic development of the settlement. On a wider involvement in the economy of the village can be calculated by building the car - road: Boljari - Belgrade, with a tunnel under Trešnjevik. 


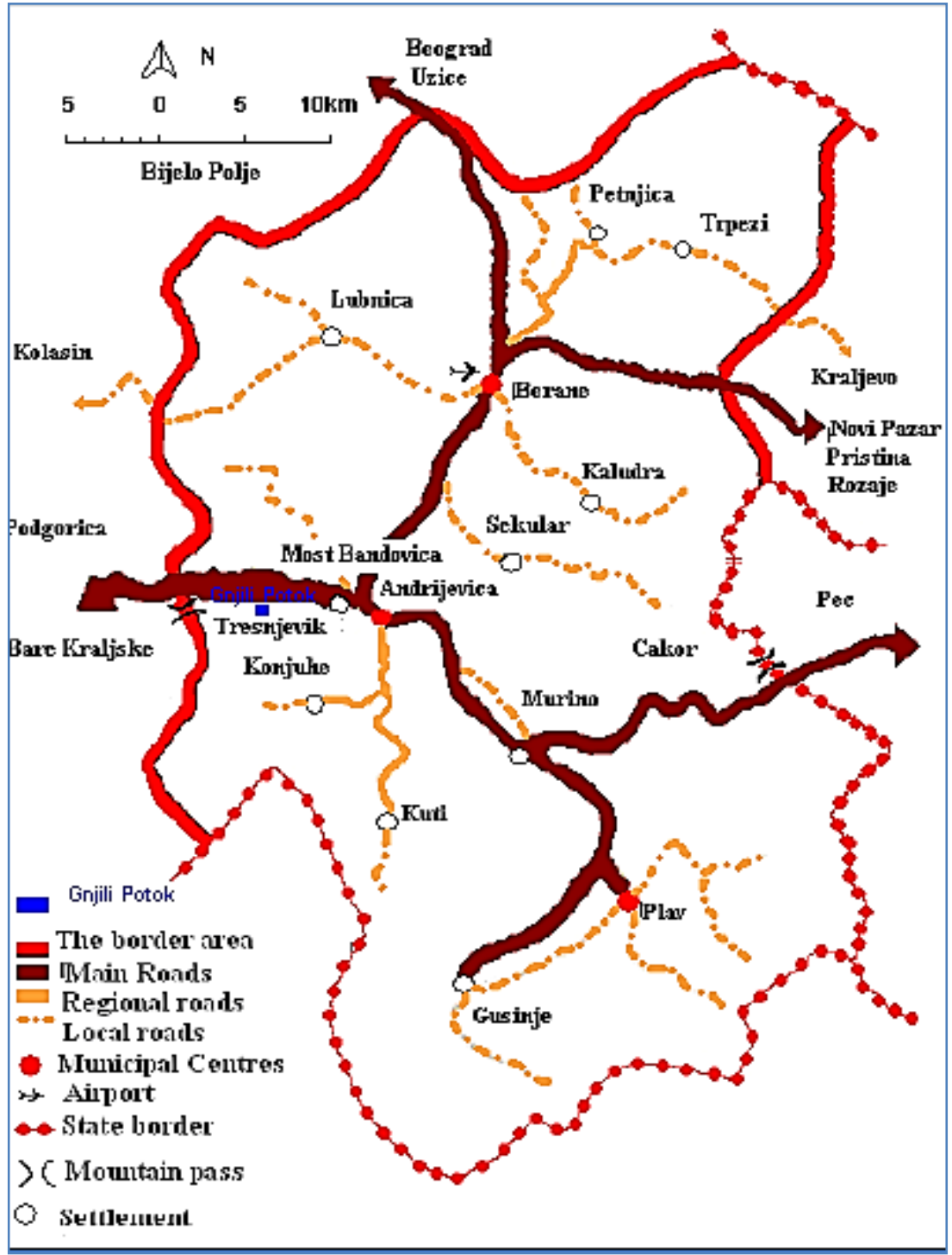

Map 1. Rural settlement Gnjili Potok on the map of northeastern Montenegro [12].

\section{2. Natural features of court}

The geomorphology of the territory terms of rural settlements Gnjili Potok mountainous character. Height difference between the highest (bottom Bulca and Lisa $1602 \mathrm{~m}$ ) and the lowest (Mill Labović $998 \mathrm{~m}$ ) is about $704 \mathrm{~m}$. We allocated approximately three height bands with lesser-equidistance of $235 \mathrm{~m}$. Altitudinal belts are grouped into two hypsometric zones. The first zone up to $1300 \mathrm{~m}$ above sea level Agricultural activity is relatively inexpensive, and it comprises the alluvial plain (groves), valleys and landscapes, which are edged with Rajova River and its tributaries in the middle mountainous terrain. This zone is characterized by milder forms of relief, and the slope of the majority of $6^{\circ}$ to $9^{\circ}$. According to Mihalic [17], the slope of $3^{\circ}$ to $7^{\circ}$, it is possible to perform all field work and the cultivation of crops, fruit trees, but to protect it from erosion, necessary contouring and seeding. Above $1200 \mathrm{~m}$ in the rural village territory, mainly represented: pastures, meadows and woodland. The second zone above 1300 meters above sea level is the most prominent entity in which sharpens contrast 
and drama of the landscape. Abundance of rainfall, contributed to the creation of green areas of meadows and forests. This zone is favorable for the development of animal husbandry. Whole relief is characterized by severe forms of relief, with a slope exceeding $12^{\circ}$ and $15^{\circ}$.

According to Mihalic [17], on the slopes of $7^{\circ}$ to $15^{\circ}$, it is necessary to use comprehensive measures against erosion, cover cropping, or terracing of land. Although it is possible in these machines, they are marginal for crop production, and are more suitable for fruit growing. Slopes of rural village across the territory of $15^{\circ}$ are unfavorable for agricultural utilization. The rational use of natural resources on these slopes, crops give way to forests. However, the Gnjili Potok in the recent past, were used to plow fields and slopes greater than $15^{\circ}$. They have most recently been abandoned or have been turned into meadows and forests. So, it appears the key problem related to determining the thresholds of rational agricultural production in the territory of the village.

The height threshold is essentially determined by the deterioration of conditions in temperature above $1300 \mathrm{~m}$ as If we take into account the results of experimental observations Čirikova [18], shows that the differences in amounts of direct solar radiation between opposite exposure, the more pronounced if the slope is greater. "This means that the temperature on the slopes that are not exposed to sunlight, the lower altitude zone, corresponding to temperatures on the slopes that are exposed to sunlight in the high band. Therefore the decrease of temperature with height more pronounced on the sunny side, but on those who are not exposed to the sun, because it is at the foot of the southern slopes of warming greater than in the northern foothills" [19]. Therefore, the sunny slopes of the rural territory of the village are more heat on them to melt snow faster and greater evaporation. For these reasons, the sunny slopes exposures spring tillage, planting and fruit ripening earlier than at the ends, which are not exposed to sunlight. The rotten creek is noted that the sunny slopes exposures: Vučji Kamen, Ravna Njiva, Ograđenica, Bregovi, Radmilica and Orničica. For exposures that are not exposed to the sun are: Lanište, Krčevine, Lomovi, Osoja, Lugovi, and the northern, northeastern and northwestern slopes Trešnjevik, Lisa and Pelinovica. Pronounced horizontal and vertical articulation of relief rural village territory is a limiting factor for intensive agricultural production, building infrastructure systems and spatial expansion of village.

Air settlement is moderate - continental. Special test environment in the territory of the settlement has not been, except for the presence of up to ten years ago, the stations to measure rainfall Vučji Kamen. The average air temperature ranges from $4{ }^{\circ} \mathrm{C}$ to $12{ }^{\circ} \mathrm{C}$. These temperature differences are particularly high in summer, when the middle and lower part of the settlement, the air heats up more than the top and the saddle Trešnjevik at night in these colder air raid, so the difference between day and night temperatures, ranging up to $10{ }^{\circ} \mathrm{C}$. According to the vertical gradient with increasing altitude the mean annual air temperature is lowered and is: on $1000 \mathrm{~m} 7,0^{\circ} \mathrm{C}$, on $1200 \mathrm{~m} 6,4{ }^{\circ} \mathrm{C}$, on $1400 \mathrm{~m} 5,8{ }^{\circ} \mathrm{C}$, on $1600 \mathrm{~m} 5,2{ }^{\circ} \mathrm{C}$. According to Rajović and Rajović [11], in the first zone to $1300 \mathrm{~m}$ above sea level, with a period mean daily temperature $\geq 5{ }^{\circ} \mathrm{C}$ lasts 203-212 days, during which time it accumulates from 2102.0 to $2444.3^{\circ} \mathrm{C}$. Period with mean daily temperature $\geq 10^{\circ} \mathrm{C}$ is $119-140$ days and accumulates around 1584.8 to $1948.7^{\circ} \mathrm{C}$. Period with mean daily temperature $\geq 15{ }^{\circ} \mathrm{C}$ lasting 9-36 days and accumulates around 83.2 to $548.8^{\circ} \mathrm{C}$. "Such temperatures allow foster the corn, potatoes, fruits and Central Europe. Besides plant are relatively good conditions for the development of livestock production "[19]. In the second zone, which includes the territory of the settlement of $1300-1600 \mathrm{~m}$ above sea level, with a period mean daily temperature $\geq 5{ }^{\circ} \mathrm{C}$ lasts 194-203 days, during which time it accumulates from 1759.7 to $2102.0{ }^{\circ} \mathrm{C}$. Period with mean daily temperature $\geq 10{ }^{\circ} \mathrm{C}$ takes $98-119$ days and accumulates around 1220.9 to 1584.8 
${ }^{\circ} \mathrm{C}$. "These are mostly steep mountain slopes, covered with dense forest. Predominantly flat terrain of meadows, while the area under plow insignificant (grown mainly potatoes, barley and oats) "[20]. As stated by the locals, it is striking just a little humidity in the summer months, which is very adverse effects on agricultural crops, especially row crops. Cloud is the highest in the winter months, which is considered quite normal. In contrast, small sky coverage in July and August, along with other adverse agro-climatic elements, affects the occurrence of drought. Based on data from the stations to measure rainfall in Vučji Kamen, the greatest amount of rainfall is excreted in May, November and January, and the lowest in July. The prevailing winds in the winter months are northwest and north, and in the remaining month's south wind. North and northwest winds, bringing dry and stable weather, perfect for a leisure trip during are summer and winter. The winds from are south direction is diversified in the winter, when making significant amounts of snowfall. According to data from the Climate Atlas Yugoslavia [21], snow cover at a height of approximately $1500 \mathrm{~m}$, began to be formed in early or mid-October and lasts until the end of May, and at a height of about 1000 $\mathrm{m}$, which is almost the lowest point is Gnjili Potok, snow cover begins to form in midNovember, and the last day of the duration of snow cover at the end of the second week of April.

Hydrographic characteristics Gnjilog Potoka indicate very diverse and significant water resources, as well as natural wealth. In terms of rural settlement hydrographic Gnjili Potok, belongs to a highly developed hydrographic network. In this sense, in the territory of the village, there is evident water energy Rajova River. Whatever which way you go - to the foot of are Lisa, which is source of, or downstream to Dubokalj, you will encounter an impressive scenes, which could be enough for a television series eco - reportage. Without any bias, it is safe to point out that Rajova River, a great place for a picnic, if not for a living, in any case, once a day, which is extremely interesting and friendly. Going down a river, you come to small and large vortices. In some places, the riverbed is carved so that the resulting real natural pools, some depth meter and a half, or two, in which the water in a mighty waterfall descents as from the "National Geographic". There are few true lovers of nature and those of others, which deal with this gem. Proof of this is that we have not noticed anywhere no matter what kind of environmental devastation. Water color is unusual; it changes depending on the day, the shadows cast by the water, and the surrounding Job's willow tree [9]. Along the whole Rajova River is attractive for picnic and recreational tourism, and it are certain that in the area waiting for the bright future. Swimming season the Rajova River can be defined as a period in which the monthly water temperatures over $18{ }^{\circ} \mathrm{C}$ and the mean air temperature over $20^{\circ} \mathrm{C}$. However, the conditional temperature limit of $18{ }^{\circ} \mathrm{C}$ cannot be a point of bathing in this case taken as an absolute rule. No, it can, first of all, as Gnjilog Potoka residents are relatively well acclimated to the temperature conditions of river water for corresponding average value greater or equal to $15^{\circ} \mathrm{C}$.

We should not be unfair or the tributaries of the Rajova River! Although differing in the length of time and amount of water to carry, they are almost equally crisp and clear, just as quick and cold. So Rajova River on both sides and the entire length of the basin receive a number of sources, streams and creeks. On the right: Trešnjevičku Rivers, Brestov do, Vranjak, Vrelo, Laz, Žunjački stream, Jagodnjak, Ravni lom, Jelar, Ornički and Laništski stream. On the left: Parlog, Laščić, Radmilički stream, Bakin stream, Gnjili stream and Suvi stream. In Rajova River, their habitat, and found a brown fish - trout. Until the mid-nineties, when the hand is caught, Rajova Rivers abounded with trout so caught specimens of about 35 $\mathrm{cm}$ in length and weighing about $35 \mathrm{o}$ grams were common. Today such examples are rare. In recent years, the trout Trešnjevička River almost non-existent, while the Rajova Rivers there 
was a serious decline in fish populations. The most common disturbing factor, however, is too much load on fishing, which includes not only legal fishing, but the first poaching. The main reason for extreme fishing pressure is insufficient and unprofessional conduct fishing controls, as well as legally non-application of protective measures in the fishery. The second item is a direct factor threatening the habitat degradation in the form of physical habitat changes, for example, the formation of water abstraction for irrigation groves. The third item population risk factor for brook trout to restock. This activity has not yet taken any momentum, and now it's up to the author's knowledge of the text, not restocking Rajova River. Mostly it seems attractive to water the valley of Lima. In the area of Gnjilog Potoka, there are a number of independent sources. Among the most prominent spotlight: Osredak, Source Lomovi, Njive Đinovića, Lanište, Ornice, Source Perinka, Source Vukotića, Carevine Rajovića, Parlog, Jelar, Butrinjak, Banjišor, Ćosak, Source Novovića... [9]. Sources are quite strong, dry; water them cold and very pleasant to drink. Of course, all the attention they deserve and the resources that are located close to the house and sources located in the pasture: Trešnjevik and Ljuban. Water as a natural resource has a range of options from the standpoint of - hydropower potential, market valuation and ecology. Economic use, protection and rational approach to water resources, can have a very positive impact in the future development of rural settlements Gnjili Potok [10].

On the territory of the present rotten Brook are two types of soil automorphic and hydromorphic with variations. The first class of automorphic land includes undeveloped and underdeveloped land (A - S profiles). Spotlight on rural territory colluviums, mostly represented on the slopes: Trešnjevik, Lisa, Pelinovice in the western part of this area - above the site: Lanište and Krčevine. For the second class (A-S profiles) automorphic soil characteristic is continuously developed and conspicuous morphological humus horizon. This class in a rural village territory is composed of four soil type's Calkomenasol, rendzina, rankers and vertisols. Calkomenasol occurs on: Lomovima, Ornicama, Small Laništu, Good Rtu, Žunjacima, Trešnjeviku, Paljinama. Rendzina to: Ravnoj Njivi, Radmilici, Laništu, slopes Trešnjevika, Paljina, Milovog Dola. Rankers to: Trešnjeviku, foot Lise and Pelinovice. Vertisols is most prevalent in Ravna fields and groves. The third class consists of land automorphic land $(\mathrm{A}-(\mathrm{V})-\mathrm{S})$ and $(\mathrm{A}-(\mathrm{V})$ - R) profile is characterized by the appearance of the horizon $(\mathrm{V})$, which sits on the loose substrate or on a compact system. On the territory of rural settlements are represented by two types of eutric camisoles and district. Eutric camisoles are related to the drier parts of the river terraces Rajova River and its tributaries. Most favorable for crops and gives good yields. District camisole occurs in the northern slopes of the rural territory. Natural vegetation of the area consists of a variety of deciduous and coniferous forests, and therefore called brown forest land. Cover almost the entire hill mountain rim rural village territory. The fourth class consists of eluvia soil - soil alluvial (A E - V - S or A- E - V - R) profile: luvisols, podsol and brown podsol soil. Luvisols occupies relief of mild forms of rural territories of settlements dating from the terraces with the presence of clay - sand layer. Podsol soil is cooler and wetter parts of rural territories, where the average annual temperature below $7{ }^{\circ} \mathrm{C}$. Second row (row B) is hydromorphic. For hydromorphic characteristic occasionally or permanently excessive moisture throughout, or are top or bottom of the profile. For are studied rural territory, represented four classes of hydromorphic soils: hipogley, enegley, seemingly and amphigley lands. The first class consists of hydromorphic soil epigley land, and represented pseudogley and stagnogley and generally fall into unfavorable and little productive land. Usually related to are alluvial plain of is Rajova River, cerise and oak forests and oak and hornbeam community. The second class consists of hydromorphic soil hipogley land. The highest share of Gnjili Potok of this 
type of land meadow occupied land. The third class of hydromorphic soils in the studied territory makes hums fluvisol. There are as individual genetic soil type, the profile of (A - S $\mathrm{G})$ and is mostly covered with grass vegetation. The fourth class of hydromorphic soil makes one type of land - lowland required. Most dominant appearance of this notice in are groves of land Labović (near the mill Labović), Rajović groves (near the mill, "Božović"), the site of the groves, under Rajova port. For a brief analysis of natural features and genetic characteristics of the soil types resulting necessity to take measures repairs productive properties of the soil. Ameliorated processing, deep plowing and sub soiling land with adverse compact horizons, soil layer shall be developed and homogenized to a certain depth, entering fertilizer using plows into deeper layers where it reduces excessive percolation of water in them. Such measures usually have lasting effects; because they are more or less change the primary soil properties. Besides regular processing is applied for planting, weed control, fertilizer and introduction for the other needs of the plants that are grown [22].

To set are landscape of rural settlements Gnjili Potok, of particular importance biogeography characteristics. Flora consists of forest and grass vegetation. When the tree species in question, saying that Gnjilog Potoka forest and deciduous and coniferous, and even sometimes mixed, but it is deciduous, much more. Tree species has no end. Fir, spruce and pine, probably, are most. Yet the diverse deciduous trees: beech, certainly, mostly, but her range Rajova River and its tributaries, and the heels: willow, poplar, alder, oak, oak, ash, birch, elm, Not to mention the lower trees and bushes: hazel, alder, black locust, cat, fiddle, elder and an endless number of others, as the spring and give you nice color to the settlement. Some sites carry the rural territory and named after the deciduous and coniferous forests: pine, fir, beech United. Taken as a whole, Gnjili Potok in relation to the area to cover, it is rich in forests. The share of the total area of forests in rural territory is about 459 acres, or about 52 $\%$ of the total territory of the rural settlements. Wood processing in rotten creek to now it is not, devoted special attention. Based on the use of forest resources, this industry has so far directed its development exclusively for the residents, while residential construction (lumber, wood panels ....), or burned as fuel. The chance of settlements in is unused possibilities for the production function, ensuring all products from the forest, which can be valorized through the production of wood volume and other forest products. In doing so, the main product is considered a tree, and all the other side - incidental.

The other products are some of the woods that are gaining increasing importance: venison, fish, snails, berries and seeds, medicinal, aromatic and spice plants, fungi, resins, essential oils, juices, bark, bats, leaves, peat, stone, gravel, sand... Taking into account the habitat conditions, rotten grass cover stream, could be divided into: the valley meadows in moist habitats, meadows and pastures, predominantly associated with a belt of oak and beech forests and alpine meadows that reach to the bottom: Lisa, Pelinovice and Trešnjevik. "Flora of forests and pastures enriched with various kinds of herbs and edible fungi. Most of them occupy a high place in folk medicine, pharmaceutical production, which is very important for the tourism development. Herbs rich in its diversity, physiological and pharmacological action, and a healthy quantity of raw materials, offers unimagined possibilities in the development of health and educational tourism. The most important species of medicinal plants from the commercial aspects are yarrow, thistle, birch, hawthorn, horsetail, cranberry, gentian, wild thyme, omen, blueberries, mint, blackberry, raspberry, dandelion, thyme, and nettle. Of forest products: hawthorn, juniper, strawberry, cornelian cherries, blackberries, raspberries, blueberries, saffron, rose hip, and mushrooms: porcini, black trumpet mushrooms ..."[23]. 
Data on purchased quantities of berries have been documented, so it is impossible to record all the quantities by species. The problem of adequate collection and, in general, the whole treatment of herbs could be solved by building a plant for the processing of medicinal plants in the neighborhood. Meadows and pastures are covered with juicy mountain meadow grass and flowers, so that together with forests, a special landscape-decorative value rural village territory. Belt noise is particularly interesting as a living space of venison, birds, fish and insects that. Is the pearl of the unique natural beauty and unspool nature. From the tourist point of view has significant resources and a predisposition to the development of different forms of tourism, such as fishing, hunting, adventure and adrenaline.

\section{3. Socio-economic factors}

From the standpoint of economic orientation, population Gnjilog Potoka is historically the Second World War, was agricultural and livestock-Farming settlement. "After World War II, at an earlier stage, through the launch of enthusiasm and a great social commitment, as many began to change and what to build: the house, somewhat in the backyard in production, rural infrastructure .... The house began to get better solutions in construction (more space, better and stronger building materials such as brick, concrete bar, tiles), the yard began to differentiated the "garden" with vegetables and flowers (fences prevented the livestock and mercury that enters the garden) and the economic area in which the economic activity shall do"[1]. The settlement received electric lighting, agricultural machinery, better seed varieties, better livestock... However, the enthusiasm, the exodus ended in mid-sixties and early seventies, discrimination of rural settlements in much better perspective of life and the work achieved in the urban areas. For residents of Gnjilog Potoka, especially in Berane, Podgorica, Belgrade or temporary work abroad. "This is a classic example of the phenomenon that is essentially invisible to many workforce that was not enough, or just a little employed in agriculture in rural areas, the rapid development of the industry, at the beginning of the development of the trigger and go to it, and that was evident in and decrease in the countryside, and the concentration in the city" [24]. Here are some demographics [8], to support this:

1. The population is between the 1948 to 2009 decreased from 325 to 81 , or $75,1 \%$. Based on the statistical data of the Statistical Office of Montenegro [25], is characterized by continuous changes in demography (1948 - 325, 1961-281, 1971 262, 1981-199, 1991 - 178, 2003 - 111), and survey research 2009 year 81 resident, it appears that the abandonment of the village is identified with the process of industrialization that began in mid-sixties and early seventies. The strategy of economic development of the former, were based on industrialization, which had a primary mission "to the individual farmers, industrial workers create, foreign migrants, subcontractors, specialty trade producers, seasonal workers ... and they all represent, sign change their living beings"[26]. According Kostić [27] "abandonment of agricultural holdings was so fast, that industrialization leading to the reduction of the population in the countryside ... That was unknown in the world, caused the intense process of migrations of rural population to the cities ". Gnjili Potok that effect.

2. Changes in the age - sex structure of the population of the village suggests basic empirical type population - regressive, the total population, the greater the share of the elderly population. Such distorted age structure has an impact on the return movement of the population, but also to all other elements of our population that is of major 
importance for the development of population and socio - economic activity of the settlement. The age structure of the population of the village, the number of young people from 0 to 19 in the total population is 12 , younger adult from 20 to 39 years is 18 , older adult from 40 to 59 years old were 26 and 60 years and over is 26 . Of the total population in the age group 0 to 19 years there were 8 men and 4 women, 20 to 39 years , 13 men and 5 women, 40 to 59 years, 13 men and 13 women. Analyzing these data, we note that the population of the village of old and the disproportion of male and female population were affected by greater participation of women in migration, and girls from the village, they left the city and there are married. It is interesting that of the 26 men in the neighborhood (older than 20 to 59 years), unmarried, on 17. What is most disturbing in the age structure of the population of the village is the total number of young people (12), which just emphasizes that it is a declining birth rate, which can lead to the reproduction of the population in the settlement. A contingent of the working time (men 15 to 64 years (31)) and women aged 15 to 59 years of age (19), as a contingent of fertility (female population aged 15 to 49 years) with a total number of 11; a demographic framework is inadequate for the formation of labor in the colony. If you do not take adequate socio - economic measures, the structure of the population of the village is likely to continue in the future, which will adversely affect the future social and economic development of the settlement.

3. The factors that could affect the demographic development of the settlement, educational characteristics, have a very important place. Therefore, analyzing the educational characteristics of the population, in addition to self-value that this factor is, it may also indicate the impact that has on the socio - economic development of the settlement [28]. Of the total population of the settlement in 2009, with incomplete primary education are 35 residents, with a degree in elementary education with 20; with a degree in secondary education are 14 people, while higher education has two inhabitants. Such a qualification structure of the population of the village is the result of the emigration of highly educated population in the economically developed centers of Yugoslavia. Specifically, in the area there is a basic four-year school, which he attended in 2009, 3 children buttery settlements, and 6 students from the village to the elementary and middle schools in Andrijevica, leaves and comes back foot. Length of the traveled road is $9 \mathrm{~km}$. The lack of secondary and higher schools in Andrijevica and Berane conditioned the departure of young people from the settlement. Structure of population, educational attainment is associated with other parts of the population, and in a way they prefer. Bearing in mind that are settlement represented mostly agricultural population, and given the degree of socio-economic development, there has not been expected that the structure of the population by educational attainment is at a higher level.

4. As a basic form of existence, the whole family during the occurrence of the development of the village was a pillar of the organization of life and economic activities. Some reasons for its extinction are deep, as the reasons for termination of life in many rural areas of Montenegro. Probably that's the wrong attitude of the society towards the family and the relationships within it caused the disturbed relations in other spheres of life and work. It is not possible at this point to go into an analysis of the importance of the family in the development of population and economy, and agriculture in the colony. "Modern science has neglected are role of the family in the formation of socio - economic processes, making the totality of these 
processes cannot explain, and some of them get stencil - an abstract form" [29]. Using the features of the family or household can be seen in the different characteristics of the population in the village. However, in most cases the family coincides with the household and through consideration of household characteristics can be analyzed and the characteristics of the family [28]. In the settlement we noticed a large number of elderly households and almost half of households with one and two members. The total number of households in the village 2009 year there are 5 households with one member, 8 households with 2 members, 4 households with 3 members, 6 households with 4 members of two households with five members and two households with 7 members. According to the National Statistical Office of Montenegro [25], in is settlement in 1948 were a total of 71 households, according to data Rajović [8], 27 households in 2009. This data indicates that in the neighborhood played very intense changes in the number of households.

For a complete consideration of the dynamics of emigration of rural settlements Gnjili Potok will use the data Rajović [6], Rajović and Rajović [11] and the displaced population Gnjilog Potoka is grouped into four homogeneous groups:

a) The first group includes Montenegro, which has the largest expatriate population representation Gnjilog Potoka ( 88 households with 330 family members). Review by municipalities as follows: Berane (21 households with 93 family members); Kolašin (6 households with 21 members of the family); Bar ( 2 households with 4 members of the family); Budva (16 households with 53 members of the family), Gusinje (1 household with 3 members of the family); Bijelo Polje (1 household with 3 members of the family), Cetinje (5 households with 17 members); Podgorica (34 households with 127 family members); Andrijevica (1 household with 5 members) and Tivat (1 household with 4 members of the family).

b) The second group comprises the territory of the Republic of Serbia (47 161 households with a family member). Browse by cities and municipalities as follows: Belgrade (23 households with 88 members); Priboj (5 households with 20 members); Priština (3 household with 10 family members) Peć ( 5 households with 16 members); Đakovica and Sombor (2 households with 5 members); Čačak (2 households with 7 family members); Užice and Svilajnac (2 households with 8 family members); Niš and Topola (3 households with 7 family members). After 1999 the Kosovo and Metohija with 9 households with 27 family members were displaced in the area of Central Serbia and Belgrade.

c) The third group includes the Republic of Serbsky and Bosnia and Herzegovina (6 households with 20 members) and Croatia (1 households and one family member). Review by municipalities and settlements look like this: Adzići ( 2 households with 5 members); Busovača (1 household with 4 members of the family); Brčko (1 household with 4 members of the family); Bihać ( 1 household with 4 members of the family) and Zenica (1 household with 3 members of the family). After the breakup of the former Yugoslavia, 2 households with 7 family members have returned to Montenegro. No matter what is taking place here, and the migration process, its intensity is most minimal.

d) The fourth group includes residents of the settlement were moved to work abroad (41 households with 115 family members). Browse by country is as follows: Denmark (25 households with 84 members of the family), USA ( 9 households with 12 members), 
Germany (3 household with 10 family members), Australia ( 2 households with 5 members) and France ( 2 households with 4 members of the family).

e) In commuting the settlement involved four people: 1 (Andrijevica), 2 (Berane), 1 (Mateševo). Seasonal migration includes nine villagers, who mostly do business in restaurants during the tourist season on the Montenegrin coast.

The motives for leaving agriculture and settlements were numerous. We will be reduced to the most important ones, which, in the opinion of Kalezić [30], and the base:

a) Provision with work requirements, development, compensation, housing, and therefore higher and more stable income provided by the city or the foreign environment. The former Yugoslavia, Montenegro and naturally, within the limits of its economic opportunities, they could not provide the necessary resources for agricultural production in the countryside, and other conditions that allow permanent employee recruitment.

b) Existential security that comes from a high degree of certainty that the inclusion in the labor market, industrial, or temporary work abroad, through an investment of labor, makes a certain income, resources to survive. In agriculture, the former Yugoslavia, Montenegro, then, that was subject to significant influence of external factors, there is uncertainty about jobs, all of which led to a fear of security collateral material conditions, to maintain its own existence.

c) Inclusion in the industrial market working, or going to work temporarily abroad, the employee on that basis, is entitled to health care (themselves and their families), and the conditions for retirement, which is an important element of his social security.

d) The general conditions of life in the town, or go on temporary work abroad emigrated Gnjilog Potoka residents have secured far greater opportunities for higher education for children and cultural life, full health care and other benefits to the city, provided that the foreign communities in relation to the homeland, which was a significant motive for the departure from the settlement and the state.

Economic - geographical factors of development, indicate the social and economic life of the population in the settlement. Below are listed the potentials and limitations of rural settlements Gnjili Potok.

The overall agricultural production in rural territory must rely on livestock. Gnjili Potok is hilly - mountainous area, and most of the agricultural land are meadows and pastures (267 ha), which provides excellent conditions for the development of animal husbandry. For rural territory can be extensively grown: cattle, sheep, swine, goats, poultry and produce significant amounts: meat, milk, eggs. First of all, we mean the mini-farm sheep and cattle. In doing so, the civil works, planning and procurement of appropriate equipment, farm equipment and preparing for production of animal feed, as well as the acquisition of part of the basic herd (breeding cows and bulls, sheep and rams), whose reproduction would gradually replace existing heads. Such households would then be able to produce cheese and other dairy products obtained by standardized technology, with a specific container. Products, over time, could be a trademark, and even the label health foods. Successfully earning this mini farm means a perfect organization and coordination, and in any cases the existence of centers for milk, cheese, cream, "collection" character. Location sheep, cattle, if they add the pork, goat and other farm is determined by natural conditions and the stability of the population in the settlement. In this regard, it would be necessary studies analyzing specific settlements Gnjili Potok, in terms of construction and location of a mini farm, and the types of livestock production, then the necessary capacity and investigate the possibility of cooperative 
production of higher capacity. In rural territory has a very favorable condition for farming, which involves expansion of area under vegetable crops and some industrial plants. On a small scale fields can be represented with the use of large quantities of manure, the introduction of appropriate crop rotation and tillage better, achieve higher production of potatoes and forage crops. Implementation of consolidation, in order to eliminate are current situation and the high fragmentation of farmland also one of the conditions for the recovery of farming. It is necessary to study and explore the area advantage in producing herbs. Specifically, it has been a great diversity of medicinal plants, which are organized production and farming could impose as a profitable branch of farming - cultivation of industrial crops. Growing fruit would be served on all suitable plots with the basic requirement of ensuring effective transport connectivity, rapid transport of very sensitive products. For the settlement are a very interesting and applicable idea and the concept of production of fish, especially trout. Gnjili Potok is rich in, mountain streams, especially Rajova River. The limiting factor here should be considered variable water levels, then the risk of blur, because as you know it is torrential water. In fact, it should be noted that the settlement is extremely well suited for mini ponds, which would be a separate study to examine. The fact that forests cover an area of 489 ha or $52 \%$ of the rural territory imposes a very sensitive development of forestry. It should not been allowed to be in the future treatment of forests, plans to cut more volume or some other action that would be contrary to organic agriculture and eco-tourism. The scope of cuts should be able to adjust the breeding group in the appropriate class of forests, in order to ensure on one side of the timber, and the other forest preserve quality. Because of the efficiency of planting should be afforested clear forest terrain, especially those occurring after harvest. The scope of cuts should increase and actions directed at the sanitary felling, in the maximum extent. Generally, forestry should blend with the eco-agricultural development. Analysis showed that forests can provide multiple revenue in eco-agricultural concept compared to conventional management. In rural territory, especially in localities Trešnjevik, Paljina and Ljuban hunting activity should be seen as the front line of organic agriculture and forestry and eco-tourist. Natural tourist values are Gnjilog Potoka respectable potential for future tourism development and as such offer the possibility of practicing different: sports leisure activities, fitness for a stay and rehabilitation opportunities for tourism development of special needs such as: rural tourism, hunting, fishing, sightseeing tourism, hiking in nature - in the immediate vicinity of the settlement is a natural environment. Natural terrain is perfect for hiking and climbing. Of course, no matter how natural attractiveness Gnjilog Potoka was satisfactory, they lay limitless and inexhaustible. Therefore, their use must be planned and rational [31].

Replacement of worn-out machinery in the settlement and provide sufficient propulsive power less tractors and other modern agricultural machinery for farms (either directly or indirectly - through various forms of financing, cooperation and mutual assistance), is the determinant for the smooth and timely performance in agriculture, and other works that activities in crop and livestock production. If mechanization in agriculture there is insufficient or of poor quality, as is the case with the contemplated settlement, the consequences can be reflected in the following: increased soil compaction, poor tillage, planting and care, mechanical damage to plants and fruit plants, increased losses during harvesting, conducting farming operations beyond the optimum date and "pollution" of land, water and air, pollutants from exhaust gases or chemical protection [32]. Neither farming household in is settlement does not have a tractor also, it should be noted on the territory of Andrijevica, there is not a store, stocked with spare parts for tractors, and also, there are no specialized services for the repair of agricultural machinery. Among the means of tillage in the settlement, were 
represented in a simple non-mechanical means (plow, plow), and machining, almost symbolic (in the settlement there are only two mowers). That are problem is more serious, most of the villagers, no plans in the near future, the acquisition of these assets. The most common application of means of transport, have cars and trucks. Situation is even worse, with the means of processing and refinement of agricultural-product (threshers, sellers), respectively, for the mechanization of various processes in livestock (milking machines, feeders, drinkers ....). What is especially puzzling when we look at the quantitative relations is the fact that (and at this stage of development of agricultural funds for the settlement), farms, cultivating their agricultural lands or funds borrow from neighbors, or to cope in different ways. It implies that the penetration of agricultural mechanization in the settlement was influenced by a number of factors, starting with: cost of capital equipment, lack of social support through financing their purchases through the full utilization of their problems and the rapid depreciation, up mentality - Farmers personality - his habits, attitudes, beliefs and convictions. For a correct and complete understanding of our situation with these quantitative relationships, according to Milić et al [28], should be taken into account qualitative factors (level of economic development of the village, the nature and configuration of the terrain, history, tradition ......). The degree of mechanization in agricultural livestock production is very low. The forage crops with natural lawn are usually naturally dried (hay). Fodder grains (corn, barley, oats), usually is ground in a mill. For cattle, the villagers generally use old buildings that are outdated and inadequate. The necessary leverage for the gradual development of agricultural production in the settlement is organizing advisory and veterinary services.

This is indicated not only past experiences but also that there are choices in the fast steps to improve or have improved their agricultural production. This would ensure the functioning of an integrated system to deal with research, training and contact with agricultural producers individually or collectively. To protect crops from diseases, pests and weeds in the neighborhood used hand and power sprayers. These sprinklers commonly used in fruit and vegetable production, and rarely, to protect other crops. The most widespread form of irrigation of agricultural lands is related to the use of: sprayer, hand pump and motor. Investment in processing facilities (drying) and storage, will be profitable only after ensuring sufficient quantity and quality of raw materials (fruits, vegetables), for processing. The solution to this problem would ensure better result, local products on the market and provided an incentive to further development of fruit and vegetables in the settlement, taking into account the favorable agro-climatic and environmental conditions. How drying is a seasonal business, dryers in terms of rationality, must be universal, adjustable comb with a wide range of parameters (temperature, pressure, velocity ...), allowing drying and plant different cultures (in addition to fruits and vegetables, mushrooms, herbs ...) [33]. We would like to point out, not fading beyond, in the analysis of all aspects related to the process of introducing modern agricultural machinery, that its intensity will be significantly determined by the degree of production efficiency choices orientation. Only if the overall economic measures, conditions are created for the complete use of agricultural machinery, we can expect satisfactory results in agricultural production in the studied villages. The average size of farms in the settlement amounts to 3.05 ha. Agricultural and forest land settlement, depending on the size, is fragmented into a number of plots ( 1 - 5 plots), varying in size and distance from the home garden. Distance from home garden plots, somewhere does not exceed a few hundred meters, settlements Lanište - Ornice - Field Đinovića - Lomovi or Lanište - Čair - Below Field - Lug. In contrast, there are plots located up to $2 \mathrm{~km}$ or more, Perinka, Paljina, Top of Gaja, or even 9 km Lazi over Trešnjevik. 
Assuming that the socio-economic characteristics of the settlement as a social community, a significant effect on the perception of his (lack of) attraction to life, and thus the possible migratory behavior, respondents have offered a series of constructed argument, observing the rules of the survey question wording Žutinić et al [34], (2010), modified for the purposes of this research, the pros and cons of living in the settlement compared to those in the city. Table 1 (in INSET) provides an overview of the questions asked and answers given. Based on survey data, in the form of a brief summary, we note the following important findings:

1. In the opinion of the majority of respondents $(94.5 \%)$, the most important advantage of living in the countryside is a healthier environment, and $91.6 \%$ of respondents said the environment is cleaner, while $81.3 \%$ of respondents to a more peaceful and safer life. Among those residents of the settlement, which prompted an advantage of living in the city, most, or $86.9 \%$, as the most essential advantage of living in the city, he singled out a better cultural and social life, while $68.8 \%$ think that it is a higher standard of living and job opportunities, and more possibilities for achieving social success, said $76.8 \%$ of respondents. Of the total number of respondents as the most essential advantage of living in the city, cited improved community infrastructure and $65.3 \%$ of them, or better communications $63.7 \%$ of them. Quality education and professional training, which can be obtained in an urban environment, the most important advantage is the opinion of 84.2 $\%$ of respondents.

2. Based on the data analysis, we found that only $82.8 \%$ of respondents, or $76.9 \%$ of the respondents said that the country is less crowded, and that the freer space in relation to the city, that living in the countryside humane compared to the city. Most respondents $(80.1$ $\%)$ considered that the settlement better keep the traditions and customs of the city, or $77.4 \%$ of them claimed that settlement the people longer nurture faith and religious life, and that the country stronger family ties, considered $76,7 \%$ of respondents. Citing them and to $75.9 \%$ in rural areas that are closer contact between people and the residents know one another well.

3. Respondents believe that $68.8 \%$ of them are able to earn less in the countryside than in the city._Extremely high number of inhabitants Gnjili Potok no income (46), not enough people with income - employees (6), pensioners (17), is largely a reflection of the economic backwardness. The average pension of 120 Euros. Monthly income of employees is around 250 Euros. However, at the same time $46.5 \%$ of the respondents felt that the cost of living in rural areas is lower than in the city. Respondents believe that the settlement conservative environment and claims $72.5 \%$ of respondents, that is, an individual's privacy is less in rural areas than in urban areas, $67.6 \%$ of respondents considered. According to the statements of the respondents $(84.4 \%)$, jobs in the country are difficult and wearisome, and the more physical work in relation to the city, while 75.7 $\%$ of respondents biggest problem is lack of free time, and that people in rural areas have less time to rest, according to $72.5 \%$ of respondents.

4. Survey questionnaires and the answers given to the respondents and $41.6 \%$ of them are living in rural areas worse governed and less equipped, but that living in the countryside humane compared to the city, claimed $76.9 \%$ of respondents, while $75.6 \%$ of respondents the most important advantage of living in the countryside in the settlement of healthier foods and I was in the countryside less crime, alcoholism, drug addiction, according to $69.8 \%$ of respondents. Respondents also emphasize to them and $68.2 \%$ were exposed to less stress than people in the city, and the country has no major social differences among the population, $58.7 \%$ of respondents considered. 


\section{INSET}

Table 1. Good hand / benefits and disadvantages / disadvantages of living in a rural settlement.

\begin{tabular}{|c|c|}
\hline Questions & Answers in $\%$ \\
\hline \multicolumn{2}{|c|}{ 1. We live in a healthy natural environment in harmony with nature } \\
\hline I do not agree & 1,3 \\
\hline I agree & 94,5 \\
\hline I do not know & 4,2 \\
\hline \multicolumn{2}{|c|}{ 2. The settlement is less polluted than the city } \\
\hline I do not agree & 2,1 \\
\hline I agree & 91,6 \\
\hline I do not know & 6,3 \\
\hline \multicolumn{2}{|c|}{ Personal security of people in rural areas is higher than } \\
\hline I do not agree & 2,1 \\
\hline I agree & 83,3 \\
\hline I do not know & 14,6 \\
\hline \multicolumn{2}{|c|}{$\begin{array}{l}\text { In rural areas are less crowded and more free space in } \\
\text { to the city }\end{array}$} \\
\hline I do not agree & 3,7 \\
\hline I agree & 82,8 \\
\hline I do not know & 13,5 \\
\hline \multicolumn{2}{|c|}{$\begin{array}{l}5 . \quad 5 . \quad \text { At the settlement are less crowded and more free } \\
\text { space in relation to the city }\end{array}$} \\
\hline I do not agree & 4,9 \\
\hline I agree & 76,9 \\
\hline I do not know & 18,2 \\
\hline \multicolumn{2}{|c|}{ The settlement has preserved the tradition and customs } \\
\hline I do not agree & 6,2 \\
\hline I agree & 80,1 \\
\hline I do not know & 13,7 \\
\hline \multicolumn{2}{|c|}{$\begin{array}{l}7.7 \text {. People in the settlement no longer nurture faith and } \\
\text { religious life }\end{array}$} \\
\hline I do not agree & 5,7 \\
\hline I agree & 77,4 \\
\hline I do not know & 16,9 \\
\hline \multicolumn{2}{|c|}{ 8. Healthier food on the settlement } \\
\hline I do not agree & 5,4 \\
\hline I agree & 78,5 \\
\hline I do not know & 17,1 \\
\hline \multicolumn{2}{|c|}{ 9. In rural areas are stronger family ties } \\
\hline I do not agree & 5,1 \\
\hline I agree & 76,9 \\
\hline I do not know & 18,2 \\
\hline \multicolumn{2}{|c|}{$\begin{array}{l}10 . \quad 10 . \text { Closer contacts are between people of the settlement, } \\
\text { the villagers know }\end{array}$} \\
\hline I do not agree & 5,0 \\
\hline I agree & 75,9 \\
\hline I do not know & 19,1 \\
\hline \multicolumn{2}{|c|}{ 11. Our settlement was less crime, alcoholism, drug addiction .... } \\
\hline I do not agree & 12,8 \\
\hline I agree & 69,8 \\
\hline I do not know & 17,4 \\
\hline \multicolumn{2}{|c|}{$\begin{array}{l}12 . \\
\text { the people in the city }\end{array}$} \\
\hline I do not agree & 11,6 \\
\hline I agree & 68,2 \\
\hline I do not know & 20,2 \\
\hline \multicolumn{2}{|c|}{ 13. No major social differences between people of the settlement } \\
\hline I do not agree & 10,2 \\
\hline I agree & 58,7 \\
\hline I do not know & 31,1 \\
\hline \multicolumn{2}{|c|}{$\begin{array}{l}\text { 14. The cost of living is lower in the countryside than in the city } \\
\text { you }\end{array}$} \\
\hline I do not agree & 17,3 \\
\hline I agree & 46,5 \\
\hline I do not know & 26,2 \\
\hline
\end{tabular}

\section{Weaknesses / shortcomings}

1. The settlement is poor entertainment and cultural facilities

I do not agree

3,0

I agree

86,9

I do not know

10,1

2. In rural areas are less opportunities for education and professional development

I do not agree

I agree $\quad 84,2$

I do not know

3 . Work in rural areas is difficult and wearisome, more physical work

I do not agree $\quad 5,0$

I agree $\quad 84,4$

$\begin{array}{ll}\text { I do not know } & 10,6\end{array}$

4. In rural areas are less able to achieve social success

I do not agree $\quad 7,3$

I agree $\quad 76,8$

I do not know $\quad 15,9$

5. Residents of the settlement have less free time

I do not agree $\quad 8,3$

$\begin{array}{lr}\text { I agree } & 75,7\end{array}$

I do not know $\quad 16,0$

6. People in rural areas have less time to rest
I do not agree

I agree $\quad 75,2$

I do not know $\quad 17,8$

7. The middle of the settlement is a conservative

I do not agree $\quad 5,9$

I agree $\quad 72,5$

I do not know 21,6

8. Options for earning the settlement are less than in

I do not agree $\quad 8,9$

I agree $\quad 68,8$

I do not know 22,3

9. Individual privacy is less in rural areas than in

urban areas

I do not agree $\quad 9,0$

I agree $\quad 67,6$

I do not know $\quad 21,5$

10. Utility services (water, electricity, heating, ...) of

the settlement, is worse than the city

I do not agree $\quad 13,3$

I agree $\quad 65,3$

$\begin{array}{ll}\text { I do not know } & 20,4\end{array}$

11. Greater isolation of traffic in the settlement

I do not agree $\quad 16,1$

I agree $\quad 63,7$

I do not know 20,2

12. Living in rural areas are poorer and less well equipped furnished

I do not agree $\quad 23,4$

I agree $\quad 46,1$

I do not know $\quad 29,5$ 


\section{CONCLUSIONS}

Our research records, based on similar studies Spalević [35], pointed to the fore some important moments, and relating to the socio-economic development of the settlement:

A. Potential Development:

a) The natural processes (homogeneous agro-ecological settlement together with a natural condition for rational agricultural production, natural environment without major anthropogenic activities, relatively fertile land suitable for diverse agricultural production, the existing Fund land to food security).

b) From the demographic point of view (the willingness and traditions of the inhabitants are engaged in agriculture).

c) From the economic point of view (there are still reserves of labor in agriculture).

B. Limits of development:

a) The natural processes (inadequate use of natural resources, unplanned conversion of agricultural land into non-agricultural land).

b) From the demographic point of view (expressed depopulation processes, unfavorable age and educational structure of the population, limited employment opportunities).

c) From an organizational point of view and the infrastructure (transportationdisadvantaged geographical location, poor quality of roads, public transportation does not exist, obsolete machinery, low level of development of agricultural infrastructure, lack of funding for important investment, not the existence of self-organization of farmers, lack of activity in creating a diversified business structure).

d) From the economic point of view (human resources (unfavorable age and educational structure and lack of motivation)), physical capital and finance (underdeveloped economic structure, market structure and credit system), lack of market institutions, the political environment (lack of political will and conflicts).

Based on the survey, we came to the conclusion that despite the low standard of living only a third of the inhabitants of completed gap material source of income with agricultural properties and residents better and more comfortable life mostly seen in the construction and development of rural infrastructure small business (given the large number of migrants, from the settlement), and everything that lives in the countryside and farming does not only worthy of modern man, but also attractive [36-40].

Gnjili Potok is located at the crossroads between survival and failure. The process of devastation of rural settlements is very intense. "It manifests itself in various forms. To stop the negative trends in the resort needs a new offensive and rural development policy. According to the accepted view of the economic theory of rural development is the goal of a better evaluation of natural resources, increasing their contribution to the wealth and wellbeing, especially rural residents, as well as society as a whole. European the experience in rural development policy should have been a lesson to us but at the same time adapted to local resources and initiatives" [41]. 


\section{References}

[1] Ćirić J., Fortification, Chronicle of the settlement, Center for Scientific Research of Serbian Academy of Arts and Sciences and the University of Niš, 2006.

[2] Jaćimović B., Development directions and methods of agricultural geography, from the special edition of the Department of Geography and Regional Planning, Book 3, 1985.

[3] Vešović R. J., Vasojević Tribe, “State Printing”, 1935.

[4] Dašić M., Vasojevići of mentioning to 1860, "National Book", Belgrade, 1986.

[5] Lutovac V. M., Ivangradska (Berane) Pit, Geographical Institute of the Serbian Academy of Sciences and Arts, Belgrade, 1957.

[6] Rajović V., Gnjili Potok and Trešnjevik, "Stupovi - Vasojevići", 1995.

[7] Rajović V., Time and People, "Pillars - Vasojevići", 1999.

[8] Rajović G., Journal Research and Development 15 (32-33) (2009) 75-77.

[9] Rajović G., Journal Mountainous Paths 68 (2010) 34-35.

[10] Rajović G., Journal Mountainous Paths 48 (2007) 10-11.

[11] Rajović G., Rajović D., Natural and socio economic characteristics of rural settlements Gnjili Potok, "Agency PC system", Belgrade, 2010.

[12] Rajović G., Bulatović J., Anuario Turismo y Sociedad 13 (2012) 171-184.

[13] Glendinning A., Nuttall M., Hendry L., Kloep M., Wood S., Sociological Review 51 (2003) 129-156.

[14] Corbett M., Journal of Education 28 (1-2) (2005) 52-72.

[15] Heley J., Jones L., Journal of Rural Studies 28 (3) (2012) 208-217.

[16] Joshi S., Gebremedhin G. T., Journal of Rural and Community Development 7(2) (2012) 117-130.

[17] Mihalić V., Agriculture, Agricultural Encyclopedia, Zagreb, 1967.

[18] Čirikov I. J., Agrometeorology, "Scientific Paper", Moscow, 1979.

[19] Milosavljević M., Climate, "Scientific Paper", Belgrade, 1963.

[20] Đerković Š. Z., Agricultural Development Strategy at regional economic development, Institute of Agricultural Economics, Belgrade, 1992.

[21] Hydro meteorological Service of Yugoslavia, Climate Atlas of Yugoslavia, Belgrade, 1978.

[22] Ćirić M., Pedology, Institute for textbooks and teaching aids, Sarajevo, 1991.

[23] Rajović G., Bulatović J., Russian Journal of Agricultural and Socio-Economic Sciences 9(9) (2012) 3-20.

[24] Jaćimović B., Proceedings of the Geographic Institute of the Faculty of Sciences 29-30 (1982/83) 93-107.

[25] Statistical Office of Montenegro, Censuses of Montenegro, Podgorica, 2010. 
[26] Lukić R., Civilization revolution in the countryside, "Sociology of the settlement", Zagreb, 1971.

[27] Kostić S., Farmer's industrial workers, "Working", Belgrade, 1963.

[28] Milić V., et al, Socio - economic and demographic characteristics Golaka, Department of Social Relations and Information, Padinska Skela, 1980.

[29] Boonefoyc E., Le monde est il surpleuple, Nashate, 1968.

[30] Kalezić Ž., Structural changes in the Montenegrin settlement in the twentieth century, "Victory", Titograd,1976.

[31] Rajović G., Journal Mountainous Paths 49 (2007) 10-12.

[32] Nikolić R., et al Equipping the mechanization of agriculture (2001-2010), Available from: htpp://www.poljoprivreda.info (12.02 2012).

[33] Karić M., Ivanović P., Đorđević Lj., Đorđević D., Journal Research and Development 15(3-4) (2009) 35-38.

[34] Žutintić Đ., Kovačić D, Grgić I., Markovina J., Journal Social Studies 1-2 (2010) 137-159.

[35] Spalević A., Proceedings of the Geographic Institute "Jovan Cvijić" of the Serbian Academy of Sciences and Arts 2 (2009) 138-139.

[36] Rajović G., Bulatović J., International Letters of Natural Sciences 1 (2014) 33-53.

[37] Rajović G., Bulatović J., Journal of Sustainable Development Studies 3 (2) (2013) 136-167.

[38] Okezie A., Ihugba, Bankoli Bankong., N. C. Ebomuche, International Letters of Social and Humanistic Sciences 5 (2014) 92-113.

[39] Okezie A. Ihugba, Alex Odii, A. C. Njoku, International Letters of Social and Humanistic Sciences 5 (2014) 21-34.

[40] Emmanuel Tsegha, International Letters of Social and Humanistic Sciences 8(2) (2014) 99-107.

[41] Gulan B., Radojević V., The future of rural areas in Serbia, Proceedings of the international conference "Multifunctional Agriculture and Rural Development", Belgrade, 2005. 